\title{
Exogenously Applied Antioxidants and Biostimulants Counteract the Adverse Effect of Biotic Stress in Wheat Plant
}

\author{
Sakr MT ${ }^{1}$, El-Sarkassy $\mathrm{NM}^{2}$ and Fuller $\mathrm{MP}^{3 *}$ \\ ${ }^{1}$ Agricultural Botany Department, Mansoura University, Egypt \\ ${ }^{2}$ Agricultural Botany Department, Zagazig University, Egypt \\ ${ }^{3}$ Department of Science and Engineering, Plymouth University, Uk
}

Submission: January 28, 2016; Published: November 30, 2017

*Corresponding author: Fuller MP, School of Biological Sciences, Faculty of Science and Engineering, Plymouth University, UK, Email: mfuller@plymouth.ac.uk

\begin{abstract}
Fusarium head blight (FHB) caused by Fusarium graminearum is an economically important disease of small grain wheat and responsible for the restriction in yield in warm, humid, and semi-humid areas worldwide. Whilst genetic solutions to these problems are being sought, exogenously applied ameliorants are needed to reduce the adverse effects of biotic stress $F$. graminearum. Pot experiments were carried out to investigate the effect of biotic stress on growth, yield and endogenous bio-constituents and to examine whether biotic stress caused by $F$. graminearum on wheat plants can be offset by the exogenous application of some antioxidant materials and biostimulants. Applied antioxidant materials and biostimulants increased the growth parameters, yield components and chemical constituents i,e, Photosynthetic pigments, Total ascorbic acid, Proline and Phenols of wheat plants grown in soil infested with F. graminearum compared with untreated plants but these values were less than with un infested control plants. Seaweed extracts and ascorbic acid were the most effective in increasing wheat growth, grain yield and chemical constituents under infested conditions. Higher and moderate concentrations of applied antioxidants were more effective in growth stimulation than the lower ones and more efficient in alleviation of the biotic stress. These results provide support for the field application of biostimulants and antioxidant compounds to alleviate the symptoms and effects of F. graminearum biotic stress in wheat plant.
\end{abstract}

Keywords: Wheat; Antioxidants; Biostimulants; Biotic stress; Pathogens; Fusarium graminearum

Abbreviations: FHB: Fusarium Head Blight; ROS: Reactive Oxygen Species; SAR: Systemic Acquired Resistance

\section{Introduction}

Wheat (Triticum aestivum L.) is considered the number one strategic food crop in Egypt and is one of the most important cereal crops in the world. Its grains are a staple human food and straw can be used for bedding and as a fodder for livestock. It contributes more calories and protein to the world diet than only other cereal crops. It is grown on roughly 200 million hectares with an average annual production of 600 million tonnes [1]. The cultivated area of wheat in Egypt is about 1.34 Mha with an average production of 9.5 million tonnes (7.09 t ha-1) [2]. Egypt has a currently population of 75 million people and there is a need for about 12 million tons of wheat to achieve food security and the current wheat production in Egypt does not meet the needs of its population and more than $40 \%$ of consumption are imported annually.

Increasing wheat production is one of the main targets in Egyptian agricultural policy and great attention needs to be paid to minimize the gap between wheat production and consumption.
The Egyptian cultivated area outside the Nile valley and delta could be increased by reclaiming new lands and devoting them to wheat production and the reduction in losses to both biotic and abiotic stress could increase yields across all growing regions. Fusarium head blight (FHB) caused by Fusarium graminearum is one of the most destructive diseases of wheat and therefore one of the most economically important fungal diseases in the world [3]. The importance of this disease is due both to yield reduction and to contamination of grains with FHB mycotoxin harvested from infective ears which are dangerous to both humans and livestock [4-6]. Grains infected with FHB are often shrivelled, with significantly lower kernel weight, and can be easily blown away with the chaff during threshing [7]. The reduction in grain size also affects grain quality which in turn affects grain processing qualities.

As a consequence of aerobic life for higher plants, reactive oxygen species (ROS) are formed by partial reduction of 
molecular oxygen and requires the co-existence of enzymatic and non-enzymatic antioxidants in plant cells to protect against oxidative damage by scavenging ROS. Antioxidants in plant cells mainly include glutathione, ascorbate, tocopherol, proline, glycine betaine and others, which whilst acting as redox buffers and important redox signaling components that interact with cellular compartments also have crucial roles in defense systems as enzyme cofactors. Antioxidants influence higher plant growth and development by modifying processes from mitosis and cell elongation to senescence and death. Most importantly, they provide essential information on cellular redox state, and regulate gene expression associated with biotic and abiotic stress responses to optimize defense and survival [8]. Hafez et al. [9] showed that antioxidants delay or inhibit oxidative target molecules such as lipids, proteins, nucleic acid and carbohydrates by scavenging oxygen-derived species or minimizing the formation of such oxygen-derived species. Antioxidant levels in most plants change differentially in response to environmental constraints (abiotic stress) and can also vary depending on the magnitude of pathogen (biotic) stress. Antioxidants are thought to neutralize the harmful effects of acute injury caused by reactive oxygen radicals (ROS) released during infections [10]. The role of antioxidants in overcoming the injurious effects of both abiotic and biotic stress may also be attributed to the regulation of plant development as well us up regulating plant disease resistance mechanisms [11]. Addition of exogenous antioxidants such as ascorbic acid, have been shown to lower lipid peroxidation in fungal cells and inhibit sclerotial differentiation. Endogenous up regulation of glutathione (GSH) also plays an important antioxidant role in cells by decreasing ROS level [12].

Salicylic acid (SA) is an endogenous growth regulator of phenolic nature, which participates in the regulation of physiological processes in plants [13]. It has been recorded that SA level often increases after pathogen attack [14] and it induces the expression of pathogenesis related proteins and initiates the development of systemic acquired resistance (SAR) and hypersensitivity. The accumulation of salicylic acid (SA) is an important component in the signal transduction pathway leading to SAR. Edgar et al. [15] found that exogenous salicylic acid treatment prior to inoculation with $F$. oxysporum activated defence gene expression in leaves and provided resistance as evidenced by reduced foliar necrosis and plant death. This suggests that salicylate-dependent defences may function in foliar tissue to reduce the development of pathogen-induced wilting and necrosis.

Humic acid (HA) has been shown to enhance natural resistance against plant diseases [16] and to stimulate plant growth through increased cell division, as well as optimized uptake of nutrients and water [17]. Moreover, HA stimulates soil microorganism activity which may also interact with plants through the rhizosphere [18]. Seaweed extracts (SWE) have been shown to enhance plant defense against pest and diseases
[19] and to influence the physiology and metabolism of plants. Seaweed products have also been shown to promote plant health by affecting the rhizosphere microbial community.

The work reported in this paper is the result of trying to determine whether antioxidants materials and biostimulants can be applied exogenously to alleviate induced pathogen (biotic) stress caused by Fusarium graminearum under Egyptian conditions. This may then provide an agronomic option for the alleviation of stress which could be used whilst plant breeders and biotechnologists search for genetic and physiological solutions to this problem.

\section{Materials and Methods}

Two pot experiments were performed at the Experimental Station Farm, Faculty of Agriculture, Mansoura University, Egypt, during the two growing winter seasons 2012 and 2013 in order to attempt to counteract or mitigate the adverse effects of biotic stress on wheat plants grown in infested soil with F. graminearum. Wheat grains and plants with some applied antioxidant materials and biostimulants (presoaking and foliar spray including Ascorbic acid, Salicylic acid, Humic acid and Sea Weed Extract) respectively. Wheat seeds (cv Sakha 93) were provided by the Seed Central Administration For Seed Certification Testing Stations, Dakahlia Governorate. Seeds (15 seeds per pot) were sown on November $18^{\text {th }}$ in $30 \mathrm{~cm}$ diameter pots containing $10 \mathrm{~kg}$ of air dried loamy soil supplemented with P205 at rate equivalent to $75 \mathrm{~kg} \mathrm{ha}^{-1}$ in the form of calcium super phosphate $(15 \% \mathrm{P}), \mathrm{N}$ in the form of urea $(34 \% \mathrm{~N})$ at a rate of $178 \mathrm{~kg} \mathrm{ha}^{-1}$ and $\mathrm{K}_{2} \mathrm{O}$ in the form of potassium sulphate $(48 \% \mathrm{~K})$ at a rate of $75 \mathrm{~kg} \mathrm{ha}^{-1}$.

Prior to sowing the wheat seed was surface sterilized using sodium hypochlorite $(0.06 \%$ active chlorine $)$ and then presoaked for 6 hours in the relevant treatment solution. Treatments were reapplied to plants as a foliar spray to run-off with the same treatments used at grain soaking 30,60 and 90 days after sowing using a hand-held atomizer. Inoculated pots were filled with soil and inoculated with $2 \%(\mathrm{w} / \mathrm{w})$ of the $F$ graminearum inoculum. The inoculated pots were watered and left for 3 days prior to seed sowing to ensure the distribution of inoculum fungus. All treatments were replicated 3 times and pots were arranged in completely randomized design. All pots were placed in an unheated greenhouse.

There were 14 treatments: 1- Un-inoculated control; 2-Inoculated control with F. graminearum and four biostimulant treaments each at three levels of application (low, med, high). Ascorbic acid (ASA) and Salicylic acid (SA) were applied at 100, 200 and $300 \mathrm{mg} \mathrm{L}^{-1}$ and Humic acid (HA) and Seaweed extract (SWE) were applied at 1000, 2000 and $3000 \mathrm{mg} \mathrm{L}^{-1}$. The control pots were sprayed with distilled water. In both growing seasons, samples were taken at 75 days from sowing and the following vegetative growth characters were recorded: plant height $(\mathrm{cm})$, dry weights of stems and leaves ( $\mathrm{g} \mathrm{plant}^{-1}$ ) and flag leaf area (cm2). At maturity crop yield and its components were recorded 
as: number of spikes pot ${ }^{-1}$; number of grains spike-1; grain yield pot $^{-1}$ (g) and weight of 1000 grains (g).

The following chemical constituents were determined in wheat plants 75 days after sowing: photosynthetic pigments; total ascorbic acid; total soluble phenols and proline concentration. Photosynthetic pigments were measured in fresh leaf samples $(0.5 \mathrm{~g}$ from the $3 \mathrm{rd}$ terminal leaf) extracted by methanol for $24 \mathrm{~h}$ at laboratory temperature after adding a trace of sodium carbonate. Chlorophylls and carotenoids were determined spectrophotometrically (Spekol $\Pi$ ) at wave lengths $452,650,665 \mathrm{~nm}$ and calculated according to the methodology of Mackinney et al. [20]. Total ascorbic acid content was determined using the 2,6 dichlorophenol indophenol method as described by Ranganna et al. [21] (mg 100 $\mathrm{g}^{-1}$ fresh weight). Total soluble phenols were measured using an assay based on the method of Toivonen et al. [22]. Samples containing $10 \mathrm{mg}$ of each extract were hydrolyzed in $1.2 \mathrm{M}$ of $\mathrm{HCl}$ and $50 \% \mathrm{MeOH}$ by heating at $80{ }^{\circ} \mathrm{C}$ for $3 \mathrm{~h}$. After centrifugation at $18000 \mathrm{rpm}, 0.1 \mathrm{~mL}$ portions of supernatants were mixed with $0.1 \mathrm{~mL}$ Results of folin-ciocattean reagent and $0.5 \mathrm{~mL}$ of $20 \% \mathrm{Na}_{2} \mathrm{CO}_{3}$ and allowed to stand in the dark for a minute. Absorbance was measured at $725 \mathrm{~nm}$ with gallic acid and compared to a standard known concentration. The total phenolic content was calculated as milligrams of gallic acid equivalent per kilogram of dry weight of extract.

Proline concentration of leaf tissues was measured according to the method of Bates et al. [23]. Approx. 0.5g of plant materials were homogenized in $10 \mathrm{~mL}$ of $3 \%(\mathrm{w} / \mathrm{v})$ aqueous sulphosalicylic acid and filtered. $2 \mathrm{~mL}$ of the filtrate was reacted with $2 \mathrm{~mL}$ of acid ninhydrin, followed by the addition of $2 \mathrm{~mL}$ of glacial acetic acid and boiled for 1 hour at 1000C. The mixture was extracted with toluene and free proline was quantified spectrophotometrically at $520 \mathrm{~nm}$ from the liquid organic phase. The data of all experiments were statistically analyzed using analysis of variance (ANOVA) according to Gomez et al. [24]. The treatment means were compared using least significant differences (LSD).

Table 1: Effects of applied antioxidant materials and biostimulant concentrations on growth parameters of wheat plant grown in inoculated soil with Fusarium graminearum after 75 days averaged across two growing seasons (2012 \& 2013).

\begin{tabular}{|c|c|c|c|c|c|c|c|c|c|c|c|c|c|c|c|c|}
\hline \multirow{3}{*}{ Antioxidant } & \multicolumn{4}{|c|}{ Plant Height (cm) } & \multicolumn{4}{|c|}{ Flag Leaf Area $\left(\mathrm{cm}^{2}\right)$} & \multicolumn{4}{|c|}{ Stem Dry Weight (g) } & \multicolumn{4}{|c|}{ Leaf Dry Weight (g) } \\
\hline & \multicolumn{16}{|c|}{ Antioxidant concentrations } \\
\hline & Low & Med & High & Mean & Low & Med. & High & Mean & Low & Med. & High & Mean & Low & Med. & High & Mean \\
\hline Control & 78.7 & 75.3 & 76 & 76.7 & 41.2 & 40.8 & 42.2 & 41.4 & 2.4 & 2.4 & 2.4 & 2.4 & 2.85 & 2.85 & 2.85 & 2.85 \\
\hline $\begin{array}{l}\text { Inoculated } \\
\text { Soil + water }\end{array}$ & 56 & 48.6 & 54 & 52.9 & 23.6 & 24.4 & 24.2 & 24.1 & 1.2 & 1.2 & 1.2 & 1.2 & 1.65 & 1.65 & 1.65 & 1.65 \\
\hline $\begin{array}{c}\text { Inoculated } \\
\text { Soil + ASA }\end{array}$ & 71.3 & 72 & 77.3 & 73.5 & 31.9 & 37.9 & 38.5 & 36.1 & 1.7 & 2 & 2.2 & 2 & 1.88 & 2.35 & 2.55 & 2.26 \\
\hline $\begin{array}{c}\text { Inoculated } \\
\text { Soil + SA }\end{array}$ & 64.7 & 66.3 & 65.7 & 65.6 & 31 & 36.3 & 36.5 & 34.6 & 1.5 & 1.8 & 2 & 1.8 & 1.71 & 2.11 & 2.3 & 2.04 \\
\hline $\begin{array}{l}\text { Inoculated } \\
\text { Soil + SWE }\end{array}$ & 77.7 & 76.3 & 76.3 & 76.8 & 36.3 & 38.9 & 39.9 & 38.4 & 1.8 & 2.2 & 2.3 & 2.1 & 2.35 & 2.41 & 2.71 & 2.49 \\
\hline $\begin{array}{c}\text { Inoculated } \\
\text { Soil + HA }\end{array}$ & 72.3 & 73.3 & 74.3 & 73.3 & 31.5 & 36.8 & 38.3 & 35.5 & 1.6 & 1.9 & 2 & 1.8 & 1.9 & 2.14 & 2.44 & 2.16 \\
\hline Mean & 70.12 & 68.63 & 70.6 & & 32.58 & 35.85 & 36.6 & & 1.7 & 1.92 & 2.02 & & 2.06 & 2.25 & 2.42 & \\
\hline LSD at $5 \%$ & $\begin{array}{c}\text { Antioxidant: } \\
2.6 \\
\text { Conc. : } 1.1 \\
\text { Intera- } \\
\text { ction:3.7 }\end{array}$ & & & & $\begin{array}{c}\text { Antio- } \\
\text { xidant: } \\
2.6 \\
\text { Conc. } \\
: 0.8\end{array}$ & & & & $\begin{array}{c}\text { Antiox- } \\
\text { idant: } \\
0.23 \\
\text { Conc. } \\
: 0.11 \\
\text { Intera- } \\
\text { ction: } \\
\text { N.S }\end{array}$ & & & & $\begin{array}{c}\text { Antiox- } \\
\text { idant: } \\
0.29 \\
\text { Conc. } \\
: 0.11\end{array}$ & & & \\
\hline & & & & & $\begin{array}{c}\text { Intera- } \\
\text { ction: } \\
2.7\end{array}$ & & & & & & & & $\begin{array}{l}\text { Intera- } \\
\text { ction: } \\
\text { N.S. }\end{array}$ & & & \\
\hline
\end{tabular}

ASA (Ascorbic acid) and SA (Salicylic acid): low conc.: 100, moderate conc.: 200, high conc.: 300mg L-1

SWE (Seaweed extract) and HA (Humic acid) low conc.: 1000, moderate conc.: 2000, high conc.: 3000mg L-1. 
All growth characters of wheat plants were reduced when grown in soil infested with F. graminearum. Applied antioxidant materials and biostimulants led to growth improvements at all concentrations of applied antioxidants including higher and moderate concentrations which were more effective than the lowest concentration and were acting as growth stimulants (Table 1). It was shown that the applied antioxidant materials and biostimulants increased growth parameters plant height, flag leaf area, stem and leaf dry weight of wheat plants grown soil infested with $F$. graminearum 75 days after sowing compared with untreated plants (control). SWE and ASA were more effective in increasing growth parameters of plants grown in soil infested with $F$. graminearum and SWE was the most effective in this respect. Higher and moderate concentrations of applied antioxidants were more effective than the lowest concentration.

All applied antioxidants increased wheat yield and yield components slightly when grown in infected soil compared with untreated plants

Table 2: Effects of applied antioxidant materials and bio stimulant concentrations on yield and its components of wheat plant grown in inoculated soil with Fusarium graminearum averaged across two growing seasons (2012 \& 2013).

\begin{tabular}{|c|c|c|c|c|c|c|c|c|c|c|c|c|c|c|c|c|}
\hline \multirow{3}{*}{ Antiox-idant } & \multicolumn{4}{|c|}{ Number of spike /pot } & \multicolumn{4}{|c|}{ Number of grain/spike } & \multicolumn{4}{|c|}{ Grain yield /pot (g) } & \multicolumn{4}{|c|}{1000 grains weight (g) } \\
\hline & \multicolumn{16}{|c|}{ Antio- xidant concen- trations } \\
\hline & Low & Med. & High & Mean & Low & Med. & High & Mean & Low & Med. & High & Mean & Low & Med. & High & Mean \\
\hline Control & 26 & 26 & 26 & 26 & 59 & 59 & 59 & 59 & 60.2 & 60.2 & 60.2 & 60.2 & 43.2 & 43.2 & 43.2 & 43.2 \\
\hline $\begin{array}{l}\text { Inoculated Soil } \\
+ \text { water }\end{array}$ & 10 & 10 & 10 & 10 & 28 & 28 & 28 & 28 & 8 & 8 & 8 & 8 & 29.7 & 29.7 & 29.7 & 29.7 \\
\hline $\begin{array}{l}\text { Inoculated Soil } \\
+ \text { ASA }\end{array}$ & 16 & 23 & 24 & 21 & 47 & 52 & 54 & 51 & 27.5 & 46.4 & 56.1 & 43.3 & 36.1 & 39.5 & 45.3 & 40.3 \\
\hline $\begin{array}{l}\text { Inoculated Soil } \\
+ \text { SA }\end{array}$ & 14 & 17 & 19 & 17 & 35 & 42 & 43 & 40 & 14.3 & 20.6 & 26.3 & 20.4 & 30.3 & 31.9 & 35.9 & 32.7 \\
\hline $\begin{array}{l}\text { Inoculated Soil } \\
+ \text { SWE }\end{array}$ & 21 & 25 & 26 & 24 & 52 & 57 & 59 & 56 & 40.7 & 55.4 & 62.6 & 52.9 & 39.3 & 41.7 & 43.8 & 41.6 \\
\hline $\begin{array}{c}\text { Inoculated Soil } \\
+\mathrm{HA}\end{array}$ & 14 & 19 & 21 & 18 & 44 & 51 & 52 & 49 & 20.2 & 38.6 & 43.9 & 34.2 & 34.6 & 41.8 & 42.6 & 39.7 \\
\hline Mean & 16.83 & 20 & 21 & & 44.17 & 48.17 & 49.17 & & 28.48 & 38.2 & 42.85 & & 35.53 & 37.97 & 40.08 & \\
\hline \multirow[t]{2}{*}{ LSD at $5 \%$} & \multicolumn{4}{|c|}{ Antioxidant: 2.6Conc. : 1.2} & \multicolumn{4}{|c|}{ Antioxidant: 11.0 Conc. :4.0 } & \multicolumn{4}{|c|}{ Antioxidant: 2.6 Conc. : 1.2} & \multicolumn{4}{|c|}{ Antioxidant: 9.6 Conc. : 3.5} \\
\hline & \multicolumn{4}{|c|}{ Interaction: 4.0} & \multicolumn{4}{|c|}{ Interaction: NS } & \multicolumn{4}{|c|}{ Interaction: 4.0} & \multicolumn{4}{|c|}{ Interaction: NS } \\
\hline
\end{tabular}

ASA (Ascorbic acid) and SA (Salicylic acid): low conc.: 100, moderate conc.: 200, high conc.: 300mg L-1

SWE (Seaweed extract) and HA (Humic acid) low conc.: 1000, moderate conc.: 2000, high conc.: 3000mg L-1

Table 3: Effects of applied antioxidant materials and biostimulant concentrations on photosynthetic pigments of wheat plant grown in inoculated soil with Fusarium graminearum averaged across two growing seasons (2012 \& 2013)

\begin{tabular}{|c|c|c|c|c|c|c|c|c|c|c|c|c|}
\hline \multirow{3}{*}{ Antioxidant } & \multicolumn{4}{|c|}{$\begin{array}{l}\text { Chlorophyll a content ( } \mathrm{mg} . \text { chl./g. fresh } \\
\text { weight) }\end{array}$} & \multicolumn{4}{|c|}{$\begin{array}{c}\text { Chlorophyll b content ( } \mathrm{mg} \text {. chl./g. fresh } \\
\text { weight) }\end{array}$} & \multicolumn{4}{|c|}{$\begin{array}{c}\text { carotenoids content ( } \mathrm{mg} \text {. /g. fresh } \\
\text { weight) }\end{array}$} \\
\hline & \multicolumn{12}{|c|}{ Antioxidant concentrations } \\
\hline & Low & Med. & High & Mean & Low & Med. & High & Mean & Low & Med. & High & Mean \\
\hline Control & 0.323 & 0.323 & 0.323 & 0.323 & 0.762 & 0.762 & 0.762 & 0.762 & 0.183 & 0.183 & 0.183 & 0.183 \\
\hline $\begin{array}{c}\text { Inoculated } \\
\text { Soil + water }\end{array}$ & 0.236 & 0.236 & 0.236 & 0.236 & 0.511 & 0.511 & 0.511 & 0.511 & 0.121 & 0.121 & 0.121 & 0.121 \\
\hline $\begin{array}{l}\text { Inoculated } \\
\text { Soil + ASA }\end{array}$ & 0.275 & 0.288 & 0.308 & 0.29 & 0.66 & 0.689 & 0.715 & 0.688 & 0.149 & 0.159 & 0.177 & 0.162 \\
\hline $\begin{array}{l}\text { Inoculated } \\
\text { Soil + SA }\end{array}$ & 0.268 & 0.277 & 0.299 & 0.281 & 0.655 & 0.685 & 0.699 & 0.679 & 0.148 & 0.152 & 0.171 & 0.157 \\
\hline
\end{tabular}




\section{Agricultural Research \& Technology: Open Access Journal}

\begin{tabular}{|c|c|c|c|c|c|c|c|c|c|c|c|c|}
\hline $\begin{array}{l}\text { Inoculated Soil } \\
+ \text { SWE }\end{array}$ & 0.288 & 0.311 & 0.32 & 0.306 & 0.689 & 0.711 & 0.725 & 0.708 & 0.17 & 0.173 & 0.182 & 0.175 \\
\hline $\begin{array}{l}\text { Inoculated Soil } \\
+\mathrm{HA}\end{array}$ & 0.272 & 0.287 & 0.306 & 0.288 & 0.666 & 0.688 & 0.705 & 0.686 & 0.149 & 0.157 & 0.174 & 0.16 \\
\hline Mean & 0.277 & 0.287 & 0.299 & & 0.657 & 0.674 & 0.686 & & 0.153 & 0.158 & 0.168 & \\
\hline \multirow{2}{*}{ LSD at $5 \%$} & \multicolumn{4}{|c|}{ Antioxidant: 0.043} & \multicolumn{4}{|c|}{ Antioxidant: $0.034 \quad$ Conc. :0.019 } & \multirow{2}{*}{\multicolumn{4}{|c|}{$\begin{array}{l}\text { Antioxidant: } 0.043 \text { Conc. : N.S } \\
\text { Interaction: } 0.051\end{array}$}} \\
\hline & \multicolumn{4}{|c|}{ Interaction :N.S } & \multicolumn{4}{|c|}{ Interaction: N.S } & & & & \\
\hline
\end{tabular}

ASA (Ascorbic acid) and SA (Salicylic acid): low conc.: 100, moderate conc.: 200, high conc.: 300mg L-1

SWE (Seaweed extract) and HA (Humic acid) low conc.: 1000, moderate conc.: 2000, high conc.: $3000 \mathrm{mg} \mathrm{L}^{-1}$

Table 4: Effects of applied antioxidant materials and biostimulant concentrations on Biochemical constituents of wheat plant grown in inoculated soil with Fusarium graminearum averaged across two growing seasons (2012 \& 2013).

\begin{tabular}{|c|c|c|c|c|c|c|c|c|c|c|c|c|}
\hline \multirow{4}{*}{ Antioxidant } & Total asce & acid cor & $n$ shoot & 00 g F.w & Proliı & oncen & ion $(n$ & d.w) & Tota & henols & $\mathrm{mg} / \mathbf{1 0}$ & F.w ) \\
\hline & \multicolumn{12}{|c|}{ Antioxidant concentrations } \\
\hline & Low & Med. & High & Mean & Low & Med. & High & Mean & Low & Med. & High & Mean \\
\hline & 144 & 144 & 144 & 144 & 1.8 & 1.8 & 1.8 & 1.8 & 40 & 40 & 40 & 40 \\
\hline Inoculated Soil + water & 177 & 177 & 177 & 177 & 4.4 & 4.4 & 4.4 & 4.4 & 48 & 48 & 48 & 48 \\
\hline Inoculated Soil + ASA & 244 & 311 & 363 & 306 & 3.6 & 3 & 2.8 & 3.1 & 71 & 78 & 84 & 77.7 \\
\hline Inoculated Soil + SA & 222 & 291 & 311 & 274.7 & 3.9 & 3.5 & 3.2 & 3.5 & 66 & 70 & 74 & 70 \\
\hline Inoculated Soil + SWE & 299 & 394 & 424 & 372.3 & 3.3 & 2.9 & 2.5 & 2.9 & 81 & 87 & 95 & 87.7 \\
\hline Inoculated Soil + HA & 236 & 298 & 322 & 285.3 & 3.8 & 3.3 & 2.9 & 3.3 & 69 & 74 & 79 & 74 \\
\hline Mean & 220.33 & 269.17 & 290.17 & & 3.47 & 3.15 & 2.93 & & 62.5 & 66.17 & 70 & \\
\hline \multirow{2}{*}{ LSD at $5 \%$} & \multicolumn{4}{|c|}{ Antioxidant: 46.3} & \multirow{2}{*}{\multicolumn{4}{|c|}{$\begin{array}{c}\text { Antioxidant: } 0.5 \text { Conc. : } 0.2 \text { Interaction: } \\
0.7\end{array}$}} & \multicolumn{4}{|c|}{ Antioxidant:13.4 } \\
\hline & \multicolumn{4}{|c|}{ Interaction:75.6 } & & & & & \multicolumn{4}{|c|}{ Interaction: N.S } \\
\hline
\end{tabular}

ASA (Ascorbic acid) and SA (Salicylic acid): low conc.: 100, moderate conc.: 200, high conc.: 300 $\mathrm{mg} \mathrm{L}^{-1}$

SWE (Seaweed extract) and HA (Humic acid) low conc.: 1000, moderate conc.: 200, high conc.: 3000mg L-1

\section{Discussion}

It was shown that all applied antioxidants could fully or partially mitigate the harmful effect of biotic stress of wheat plants grown in soil inoculated with F. graminearum. Applied antioxidants slightly enhanced growth and yield parameters as well as photosynthetic pigments. Moreover the endogenous non-enzymatic compounds such as total ascorbic acid, total phenols and proline were increased due to exogenously applied antioxidants. These compounds are known to improve plant resistance of wheat plants grown under biotic stress. SWE and ASA were the most effective in increasing resistance of wheat plant against F. graminearum.

Because ascorbate is a substrate for cell wall peroxidases, it may play a role in the regulation of cell wall lignification, particularly through its capacity to inhibit the oxidation of phenolic compounds by peroxidases [20]. The pathogen-induced increase in the peroxidase activity of the cell wall would be effective only in the absence of ASA. Exogenous salicylic acid treatment prior to inoculation however, appears to activate defence gene expression in leaves and provide increased $F$. oxysporum resistance as evidenced by reduced foliar necrosis and plant death. This suggests that salicylate-dependent defenses may function in foliar tissue to reduce the development of pathogen-induced wilting and necrosis [21]. Salicylic acid (SA) is an endogenous growth regulator of phenolic nature, which participates in the regulation of physiological processes in plants [22]. It has been recorded that SA level often increases after pathogen attack and it induces the expression of pathogenesis related proteins and initiates the development of systemic acquired resistance and hypersensitivity [25]. Klessing et al. [26] stated that SA appears to regulate the delicate balance between pro- and anti-death functions during the hypersensitive response. Salicylic acid accumulates at a high concentration in the immediate vicinity of incompatible infection sites and is considered a key endogenous regulator of defense responses, being involved both in localized defenses and in systemically acquired resistance [23]. Evaluation under artificial infection in greenhouse conditions indicated that all natural compounds (mannitol, oxalic acid, citric acid and ascorbic acid, the polyamines spermine and omithine and $1 \%$ anti-transpirants were effective against the pathogens Phytophthora infestans and Alternaria solani [24].

Humic acid enhanced natural resistance against plant diseases [25] and a stimulation of plant growth through increased cell division, as well as optimized uptake of nutrients and water has been reported [26]. Moreover, HA stimulated the soil microorganisms [27] which may have a biotic control effect. Several reports have indicated the efficiency of HA in reducing some plant diseases. In this respect Scheuerell et al. [16] reported effective treatments for suppression of grey mould disease caused by Botrytis cinerea. HA is a suspension based on potassium humates which can be applied successfully in many areas of plant production as a plant growth stimulant or soil conditioner for enhancing natural resistance against plant diseases and pests [28] which consequently can increase plant yield. Foliar application of HA were also shown to enhance antioxidants such as á-tocopherol, â-carotene, 
superoxide dismutase, and ascorbic acid concentrations in turf grass species [29]. Any factor such as HA which causes an increase in photosynthetic pigments will generally lead to an increase in carbohydrate content. El-Ghamry et al [30] stated that all morphological parameters, yield components and chlorophyll content were significantly increased by the application of HA (2000ppm) and interacted with amino acids.

Seaweed extracts have also been shown to enhance plant defense against pest and diseases [30] and can serve as an important source of plant defense elicitors [31,32]. Plants protect themselves against pathogen invasion by the perception of signal molecules (elicitors) which include a wide variety of molecules such as oligo and polysaccharides, peptides, proteins, and lipids, often found in the cell wall of attacking pathogens [33,34]. This work clearly demonstrated that exogenous applications of applied antioxidants and biostimulants can be a useful method to alleviate biotic stress and counteract yield reductions in wheat and opens the possibility of using exogenous applications to alleviate biotic stress in the agronomic situation. This study did not attempt to assess the economic aspects of these treatments but such an assessment would clearly be necessary to assess the efficacy of applications in an agronomic situation, however both antioxidants and biostimulants are readily available and are currently used agronomically without a full understanding of their modes of action. Further work is necessary to investigate whether these compounds could be combined to work synergistically as they have different cellular modes of action. The results indicate that there are exciting opportunities for the alleviation of biotic stress.

\section{Conclusion}

These results clearly demonstrate that exogenous applications of antioxidants materials and biostimulants could be used to counteract or mitigate fully or partially the harmful affects of pathogen (biotic) stress (F. graminearum) on both physiological aspects and growth parameters of wheat plants. They are capable of restoring yield potential and may be useful in agronomic situations.

\section{References}

1. Rajaram S, Braun HJ (2006) Wheat yield potential. In: International symposium on wheat yield potential: challenges to international wheat breeding Mexico CIMMYT Report 103-107.

2. Anonymous (2013) Economic and Statistical Research Institute, Ministry of Agric, Egypt.

3. Moosawi-Jorf SA, Farokhi-Nejad S, Afarin S (2007) Study of Fusarium head blight of wheat in Khuzestan province in Iran and reporting of Fusarium Xylaroides as a new causal agent for disease. Journal of Agronomy 6(1): 212-215.

4. Soltanloo H, Khorzoghi EG, Ramezanpour SS, Arabi MK, Pahlavani MH (2010) The expression profile of Chi-1, Glu-2, Glu-3 and PR1.2 genes in Scab-resistant and susceptible wheat cultivars during infection by Fusarium graminearum. Plant Omics 3(5): 162-166.

5. Bernando A, Bai G, Guo P, Xiao K, Guenzi AC, et al (2006) Fusarium graninearum-induced changes in gene expression between Fusarium head blight-resistant and susceptible wheat cultivars. Functional Integrated Genomics 7(1): 69-77.

6. Goyarts T, Dänicke S, Valenta H, Ueberschär KH (2007) Carry-over of Fusarium toxins (deoxynivalenol and zearalenone) from naturally contaminated wheat to pigs. Food Additives and Contaminants 24(4): 369-380.

7. Bai GH, Shaner G (2004) Management and resistance in wheat and barley to Fusarium head blight. Annual Review Phytophathology 42: 135-161.

8. Shao HB, Chu LY, Lu ZH, Kang CM (2008) Primary antioxidant free radical scavenging and redox signaling pathways in higher plant cells. Int J Biol Sci 4(1): 8-14.

9. Hafez YM (2005) Biochemical and molecular studies on role of reactive oxygen species and antioxidants in plant disease resistance. PhD. Thesis, Fac. of Szwnt Istvan Univ.

10. Shahda WT (2001) Antifungal activity of salicylic acid for controlling Alternaria alternata of tomato. Journal Agricultural Science, Mansoura University 26: 6117-6129.

11. Achuo EA, Audenaert K, Meziana H, Hofte M (2004) The salicylic acid dependent defense pathway is effective against different fungi in tomato and tobacco. Plant Pathology 53(1): 65-72.

12. Lee JH, Choi IY, Kil IS, Kim SY, Yang ES, et al. (2001) Biochimie Biophysica Acta 1526: 191- 198.

13. Sakhabutdinova AR, Fatkhutdinova DR, Bezrukova MV, Shakirova FM (2003) Salicylic acid prevents the damaging action of stress factors on wheat plants. Bulgarian Journal of Plant Physiology Special Issue 314-319.

14. Metwally A, Finkemeier I, Georgi M, Dietz KJ (2003) Salicylic acid alleviates the cadmium toxicity in barley seedlings. Plant Physiology 132(1): 272-281.

15. Edgar CI, McGrath KC, Dombrecht B, Manners JM, Maclean DC, et al. (2006) Salicylic acid mediates resistance to the vascular wilt pathogen Fusarium oxysporum in the model host Arabidopsis thaliana. Australasian Plant Pathology 35(6): 581-591.

16. Scheuerell SJ, Mahaffee WH (2006) Variability associated with suppression of Gray Mold (Botrytis cinerea) on Geranium by foliar applications of non-aerated and aerated compost teas. Plant Disease 90(9): 1201-1208.

17. Chen Y, De Nobili, M Aviad T (2004) Stimulatory effect of humic substances on plant growth. In Soil organic matter in sustainable agriculture 103-130.

18. Atiyeh RM, Lee S, Edwards CA, Arancon NQ Metzger JD (2002) The influence of humic acids derived from earthworm processed organic wastes on plant growth. Bioresource Technology 84: 7-14.

19. Allen RD, Webb RP, Schake SA (1997) Use of transgenic plants to study antioxidant defenses. Free Radical Biology and Medicine 23(3): 473479 .

20. Mackinney G (1941) Absorption of light by chlorophyll solution. Journal Biological Chemistry 140: 315-322.

21. Ranganna C (1979) Manual of analysis of fruit vegetable products. Tatame McGraw Hill publishing company limited New Delhi, India.

22. Toivonen PMA, Stan S (2004) The effect of washing on physiochemical changes in packaged, sliced green peppers. International Journal of Food Science and Technology 39(1): 43-51.

23. Bates S, Waldern RP, Teare D (1973) Rapid determination of free proline for water stress studies. Plant and Soil 39(1): 205-207.

24. Gomez KA, Gomez AA (1984) Statistical procedures for agricultural research. $\left(2^{\text {nd }} e d n\right)$, Sons Willy and Sons, New York. USA. 
25. Mehlhorn H, Lelandais M, Korth HG, Foyer CH (1996) Comparison of ascorbate-dependent peroxidase activity in horseradish peroxidase types I and II and in leaf extracts. FEBS Letters 378: 203-206.

26. Klessing DF, Dumer J, Noad R, Navarre DA, Wendenne D (2000) Nitric oxide and salicylic acid signaling in plant defense. Proceedings of the National Academy of Science, USA 97(16): 8849-8855.

27. Chen Z, Malam J, Henning J, Conrath U, Sanchez-Casas P (1995) Induction, modification and transduction of the salicylic acid signal in plant defence responses. Proceedings of the National Academy of Science, USA 92(10): 4134-4137.

28. Haggag WM, EL-Khair HA (2007) Application of some natural compounds for management of potato late and early blights. International Journal of Food, Agriculture and Environment 5(2): 157163.

29. Zhang X (1997) Influence of plant growth regulators on turf grasses growth, antioxidant status, and drought tolerance. Ph.D. Thesis, Faculty of Virginia Polytechnic (Institute and State University).

30. El-Ghamry AM, Abd El-Hai KM, Ghoneem KM (2009) Amino and Humic Acids Promote Growth, Yield and Disease Resistance of Faba Bean Cultivated in Clayey Soil. Australian Journal of Basic and Applied Sciences 3(2): 731-739.

31. Khan W, Rayirath UP, Subramanian S, Jithesh MN, Rayorath P, et al. (2009) Seaweed Extracts as Biostimulants of Plant Growth and Development. Journal Plant Growth Regulation 28(4): 386-399.

32. Boller T (1995) Chemo perception of microbial signals in plant cells. Annual Review of Plant Physiology and Plant Molecular Biology 46: 189-214

33. Steiner B, Kurz H, Lemmens M, Buerstmayr H (2008) Differential gene expression of related wheat lines with contrasting levels of head blight resistance after Fusarium graminearum inoculation. Theoretical and Applied Genetics 118(4): 753-764.

This work is licensed under Creative

Commons Attribution 4.0 License

DOI: 10.19080/ARTOAJ.2017.12.555853 